\title{
Improvement of Castability and Quality of Continuously Cast Steel
}

\author{
Dieter JANKE, Zhongting MA, Peter VALENTIN ${ }^{1)}$ and Andreas HEINEN ${ }^{1)}$
}

Institute of Iron and Steel Technology, TU Freiberg, Leipziger Strasse 34, D-09599 Freiberg, Germany.

1) Betriebschef Stahlerzeugung/Sekundärmetallurgie, Saarstahl AG, Bismarckstrasse 57, D-66330 Völklingen, Germany.

(Received on May 10, 1999; accepted in final form on September 22, 1999)

Thermodynamic fundamentals on the systems $\mathrm{Fe}-\mathrm{Al}-\mathrm{O}$ and $\mathrm{Fe}-\mathrm{Al}-\mathrm{Ca}-\mathrm{S}-\mathrm{O}$ being important to metallurgy of Ca-treated Al-killed steels are analysed and discussed. The formation of liquid Ca aluminates for the improvement of castability is pursued in view of the production of Ca-treated Al-killed steels. The "Liquid window" is theoretically analysed and experimentally investigated. The top slag is formed after tapping and its composition is fairly constant during ladle treatment for both with and without $\mathrm{RH}$ treatment, respectively. However, the top slag of the degassed heats shows a lower oxygen level compared to the non-degassed heats. It is found that there exists an "inclusion path" during the ladle treatment. The inclusion path for the heats with $\mathrm{RH}$ treatment considerably differs from that of the heats without RH treatment and it greatly influences the efficiency of Ca treatment.

KEY WORDS: thermodynamics; Ca metallurgy; RH treatment; inclusions; castability; steel quality.

\section{Introduction}

Steel is one of the massively used materials and it will remain to be one of the most important materials in the next century. However, future steels will face some critical problems such as quality, price, customer demands and environmental and ecological concerns. Thus, advanced technologies are needed for the production of future steels including both the modern production process and the industrial structure. With regard to product quality assurance, it is significant to enhance process control instead of the conventional approach of product inspection and control. One of the essential tasks in the steelmaking process is to control nonmetallic inclusions. It is believed that castability, structure and properties of continuously cast steel are closely related to nonmetallic inclusions. In addition to the conventional concept, there are three ways as follows to guarantee the improvement of castability, structure and properties of continuously cast steel.

- removal of nonmetallic inclusions to extremely low levels,

- modification of nonmetallic inclusions to alleviate or eliminate their harmful effects,

- control of nonmetallic inclusions for utilization.

It is the main purpose of the present study to investigate the first two ways. The third one will be discussed elsewhere. ${ }^{1)}$

$\mathrm{Al}$ is widely accepted as a deoxidant in steelmaking process and its addition is very convenient. Al effectively reduces oxygen content in liquid steel to low levels. For example, a content of about $4 \mathrm{ppm}$ oxygen is attained at $1873 \mathrm{~K}$ with 0.02 mass $\%$ soluble $\mathrm{Al}$ at equilibrium as shown in Fig. 1. ${ }^{2)}$ However, its utilization as a deoxidant is somewhat limited due to the formation of $\mathrm{Al}$ containing oxides in liquid steel. It is experimentally confirmed that alumina inclusions easily form clusters. ${ }^{3-8)}$ Cluster inclusions such as $\mathrm{Al}_{2} \mathrm{O}_{3}, \mathrm{Al}_{2} \mathrm{O}_{3} \cdot \mathrm{MgO}$ and $\mathrm{Al}_{2} \mathrm{O}_{3}-\mathrm{SiO}_{2}$ are difficult to be removed from liquid steel and tend to cause nozzle clogging resulting in a breakdown of the whole casting process. However, nozzle clogging is possibly avoided by a precise and effective process control. Some exciting and encouraging examples were reported by Uesing, ${ }^{9}$ for example a sequence casting of $10000 \mathrm{t}$ of 68 heats through a single tundish without nozzle clogging for bearing steel was reached via the control of keeping total and soluble $\mathrm{Al}$ content at

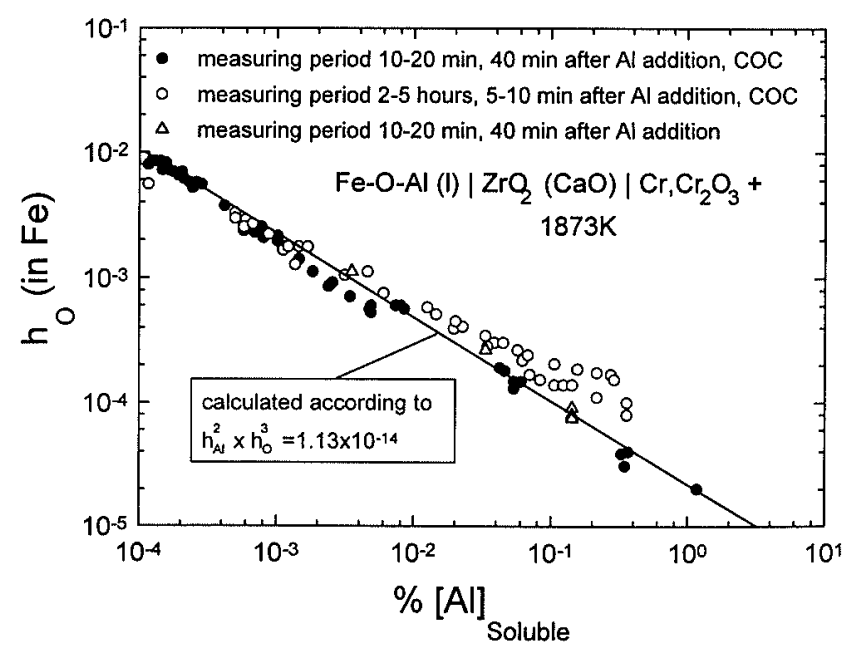

Fig. 1. Deoxidation equilibrium between $\mathrm{Al}$ and $\mathrm{O}$ in pure iron melts at $1873 \mathrm{~K}$ (COC: coulometric oxidation cell $\left.^{2}\right)$. 
virtually the same level of $0.018 \pm 0.001 \%$.

$\mathrm{Ca}$ has been frequently employed to treat Al-killed steels since the $1970^{\prime} \mathrm{s}^{10)}$ to avoid the formation of solid alumina mainly for long products, i.e. bloom/billet casting, but also in a standard practice for slab casting. ${ }^{10,11)} \mathrm{Ca}$ addition aims at the modification of solid alumina inclusions to liquid Ca-aluminates effectively alleviating and minimizing nozzle clogging. Despite the fact that calcium treatment in quality steelmaking is no longer a specialty today, the results obtained are often erratic. A "general recipe" for the correct amount of calcium addition has not been reached so far. It is experimentally confirmed that phase transformation and secondary inclusions are closely related to primary inclusions including their sizes, distributions, compositions and structures. ${ }^{12-19)}$ Thus, deoxidation practice directly influences the castability, structure and properties of steel.

Therefore, the control of nonmetallic inclusions during tapping and refining stage is of great importance to an economical production of high quality clean steels. A reliable thermodynamic analysis of aluminum and $\mathrm{Ca}-$ treated aluminum deoxidation is highly demanded for the control of formation of nonmetallic inclusions associated with Al. It is the purpose of the present study to investigate the factors of the castability of Ca-treated Al-killed steels.

\section{Thermodynamic Fundamentals on the Systems Fe- $\mathrm{Al}-\mathrm{O}$ and $\mathrm{Fe}-\mathrm{Al}-\mathrm{Ca}-\mathrm{O}$}

Reliable thermodynamic analyses for the systems $\mathrm{Fe}-\mathrm{Al}-\mathrm{O}$ and $\mathrm{Fe}-\mathrm{Al}-\mathrm{Ca}-\mathrm{O}$ are indispensable to accurately analyze the metallurgical process of $\mathrm{Ca}$-treated Al-killed steels. An effective and precise control of the formation of nonmetallic inclusions associated with aluminum for $\mathrm{Ca}$-treated Al-killed steels needs a deep understanding of the systems $\mathrm{Fe}-\mathrm{Al}-\mathrm{O}$ and $\mathrm{Fe}-\mathrm{Al}-$ $\mathrm{Ca}-\mathrm{O}$.

\subsection{Thermodynamics of the System Fe-Al-O}

$\mathrm{Al}$ in liquid iron easily reacts with $\mathrm{O}$ via the following reaction:

$$
\begin{gathered}
\left(\mathrm{Al}_{2} \mathrm{O}_{3}\right)=2[\mathrm{Al}]+3[\mathrm{O}] \\
\log K_{\mathrm{Al}-\mathrm{O}}=\log \frac{h_{\mathrm{Al}}^{2} h_{\mathrm{O}}^{3}}{a_{\mathrm{Al}_{2} \mathrm{O}_{3}}} .
\end{gathered}
$$

in which $K_{\mathrm{Al}-\mathrm{O}}, h_{\mathrm{Al}}, h_{\mathrm{O}}$ and $a_{\mathrm{Al}_{2} \mathrm{O}_{3}}$ represent the equilibrium constant, Henrian activities of $\mathrm{Al}$ and $\mathrm{O}$, and Raoultian activity of alumina, respectively.

Extensive work has been made on the aluminum deoxidation equilibria in pure liquid iron. ${ }^{20-29)} \mathrm{Al}$ though some uncertainties still exist on the equilibrium data, the main results from the different sources are consistent. These results are summarized as follows:

- The equilibrium constant, $K_{\mathrm{Al}-\mathrm{O}}$, at $1873 \mathrm{~K}$ is in the order of $10^{-14}$,

- The temperature dependence of $K_{\mathrm{Al}-\mathrm{O}}$ has been thoroughly investigated,

- It is necessary to use both the first and second order interaction parameters to carry out thermodynamic
Table 1. Values of $K_{\mathrm{Al}-\mathrm{O}}$ at $1873 \mathrm{~K}$ from different sources.

\begin{tabular}{llllllll}
\hline$K_{A 1-O}\left(\times 10^{14}\right)$ & $5.62^{*}$ & $1.26^{*}$ & $5.62^{* *}$ & $2.42^{* *}$ & $3.23^{* *}$ & $0.977^{* *}$ & $11.0^{*}$ \\
\hline Year & 1963 & 1965 & 1970 & 1976 & 1983 & 1995 & 1998 \\
\hline Ref. & $23)$ & $24)$ & $25)$ & $26)$ & $27)$ & $2)$ & $22)$ \\
\hline
\end{tabular}

* determined by chemical analysis for $\mathrm{Al}$ and $\mathrm{O}$ contents.

** determined by activity of $O$ measured with EMF sensors.

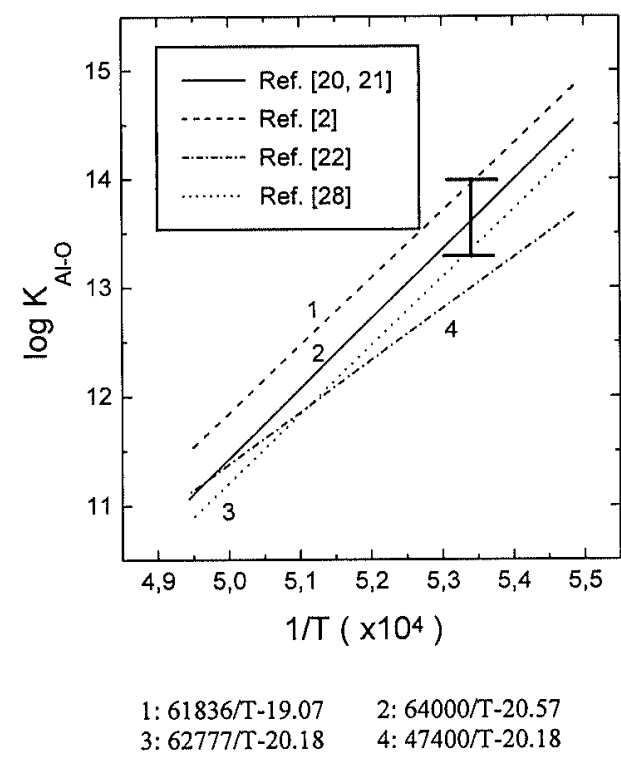

Fig. 2. Temperature dependence of $K_{\mathrm{Al}-\mathrm{O}}$ in pure iron melts.

analysis for the system $\mathrm{Fe}-\mathrm{Al}-\mathrm{O}$ when the content of $\mathrm{Al}$ exceeds about 0.2 mass $\%$ because of the strong interaction between $\mathrm{Al}$ and $\mathrm{O}$ in liquid iron.

The equilibrium constant, $K_{\mathrm{Al}-\mathrm{O}}$, was extensively investigated. Table 1 gives the values of $K_{\mathrm{Al}-\mathrm{O}}$ at $1873 \mathrm{~K}$. It is found that the equilibrium constants ${ }^{2-24)}$ determined by chemical analysis for the $\mathrm{Al}$ and $\mathrm{O}$ contents and those ${ }^{25-27)}$ by oxygen activities measured with EMF sensors tends to show no difference within the limits of experimental error. The reported values for $K_{\mathrm{Al}-\mathrm{O}}$ in Table 1 varied between $1.0 \times 10^{-14}$ and $11 \times 10^{-14}$. The temperature dependence of $K_{\mathrm{Al}-\mathrm{O}}$ is graphically shown in Fig. 2 from different sources. It seems that $K_{\mathrm{Al}-\mathrm{O}}$ varies between $1.0 \times 10^{-14}$ and $5.0 \times 10^{-14}$ at $1873 \mathrm{~K}$. The average $3.0 \times 10^{-14}$ is presently the recommended value for $K_{\mathrm{Al}-\mathrm{O}}$ at $1873 \mathrm{~K}$ and $\log K_{\mathrm{Al}-\mathrm{O}}=64000 / T-20.57$ is recommended.

The activity coefficient of oxygen, $f_{\mathrm{O}}$, is plotted as a function of $\mathrm{Al}$ content in Fig. 3. It is obvious that $\log f_{\mathrm{O}}$ is no longer a linear relation to $\mathrm{Al}$ content when $\mathrm{Al}$ exceeds 0.2 mass $\%$. Thus, it is unreliable to describe the $\mathrm{Fe}-\mathrm{Al}-\mathrm{O}$ system at $\mathrm{Al}>0.2$ mass \% when only the first order interaction parameters are used.

\subsection{Thermodynamic Consideration on the System Fe- Al-Ca-O}

The $\mathrm{CaO}-\mathrm{Al}_{2} \mathrm{O}_{3}$ binary phase diagram is well known as shown in Fig. $4^{30}$ indicating that liquidus temperature is pronouncedly lowered when the two oxides are dissolved in each other. It is clear that the principle behind the modification of solid alumina inclusions is the reaction of dissolved $\mathrm{Ca}$ with $\mathrm{Al}_{2} \mathrm{O}_{3}$ to produce liquid $\mathrm{CaO}-\mathrm{Al}_{2} \mathrm{O}_{3}$ inclusions avoiding the formation of the intermediate phases $\mathrm{CA}_{6}, \mathrm{CA}_{2}, \mathrm{CA}$ and $\mathrm{CaO}(\mathrm{C}$ and $\mathrm{A}$ 


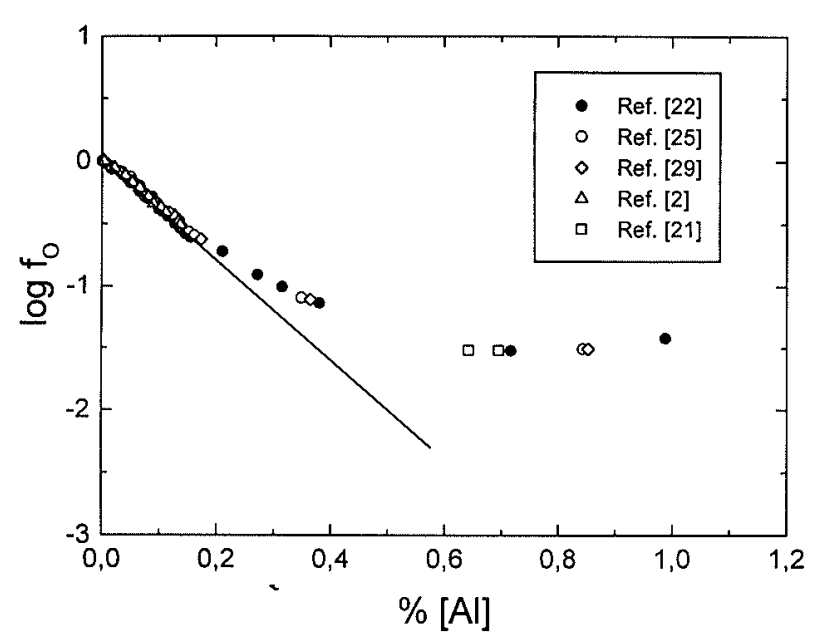

Fig. 3. Relationship between $\log f_{\mathrm{O}}$ and $(\% \mathrm{Al})$ in iron melts.

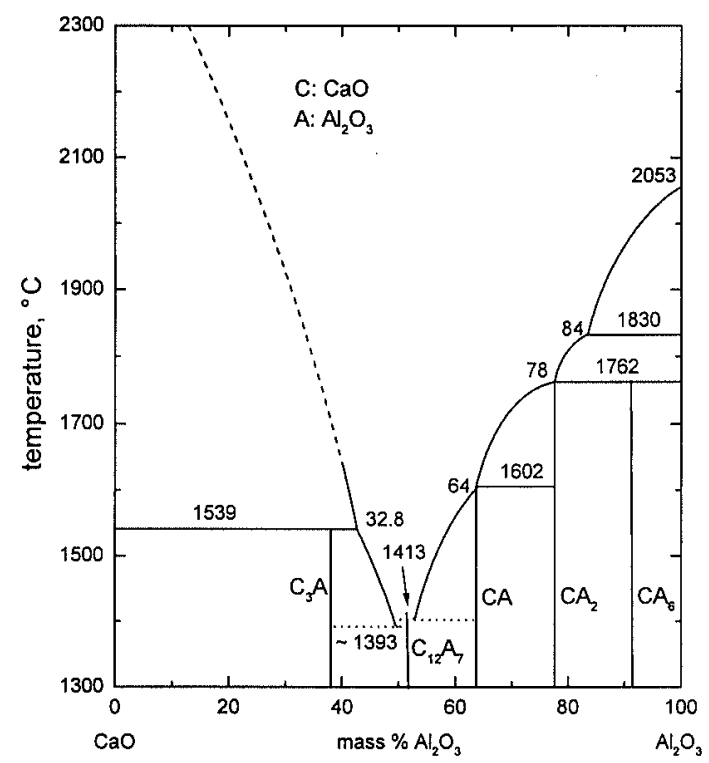

Fig. 4. Phase diagram of the system $\mathrm{Al}_{2} \mathrm{O}_{3}-\mathrm{CaO}^{30}$ )

represent $\mathrm{CaO}$ and $\mathrm{Al}_{2} \mathrm{O}_{3}$, respectively). The reaction between dissolved $\mathrm{Ca}$ and alumina can be expressed as follows

$$
3[\mathrm{Ca}]+\left(\mathrm{Al}_{2} \mathrm{O}_{3}\right)_{\mathrm{C}-\mathrm{A} \text { incl. }}=2[\mathrm{Al}]+3(\mathrm{CaO})_{\mathrm{C}-\mathrm{A} \text { incl. }}
$$

Simultaneously calcium reacts with sulfur

$$
[\mathrm{Ca}]+[\mathrm{S}]=(\mathrm{CaS})_{\text {incl. }}
$$

The overall reaction can be written as

$$
3[\mathrm{~S}]+2[\mathrm{Al}]+(\mathrm{CaO})_{\mathrm{C}-\mathrm{A} \text { incl. }}=3(\mathrm{CaS})_{\mathrm{incl} .}+\left(\mathrm{Al}_{2} \mathrm{O}_{3}\right)_{\mathrm{C}-\mathrm{A} \text { incl. }}
$$

The data of the activities of $\mathrm{CaO}$ and $\mathrm{Al}_{2} \mathrm{O}_{3}$ corresponding to the equilibrium binary system are taken from reference. ${ }^{31)}$ The solubility product of $\mathrm{CaO}$ in liquid iron has been discussed by many researchers ${ }^{32-36)}$ and $K_{\mathrm{CaO}}=h_{\mathrm{Ca}} \cdot h_{\mathrm{O}}=10^{-10.34}$ at $1873 \mathrm{~K}$ is selected in the present study.

Nozzle clogging is related to the following two situations in the case of Ca-treated Al-killed steel, namely (1) deficient addition of $\mathrm{Ca}$ results in partially liquified alumina inclusions, and (2) excessive addition of $\mathrm{Ca}$

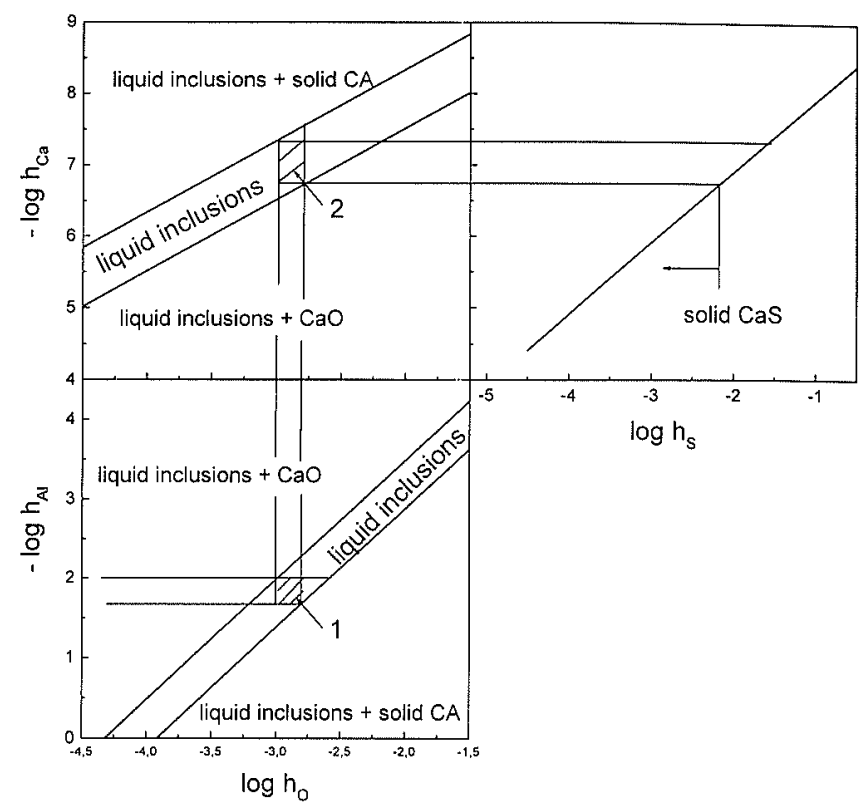

Fig. 5. Conditions for producing liquid $\mathrm{CaO}-\mathrm{Al}_{2} \mathrm{O}_{3}$ inclusions in liquid iron at $1873 \mathrm{~K}$.

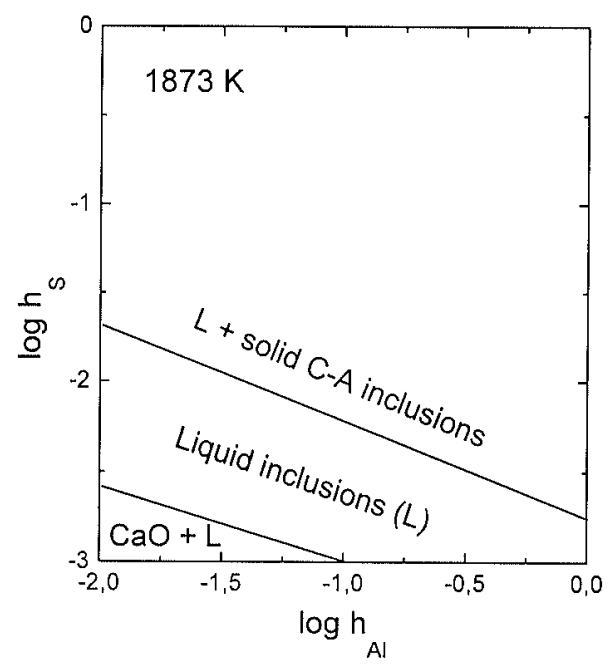

Fig. 6. Liquid window for producing liquid $\mathrm{Al}_{2} \mathrm{O}_{3}-\mathrm{CaO}$ inclusions.

results in the generation of solid CaS. Figure 5 clearly gives the prerequisites for producing liquid $\mathrm{CaO}-\mathrm{Al}_{2} \mathrm{O}_{3}$ inclusions without the formation of solid CaS. For example, setting $h_{\mathrm{Al}}$ in the range between 0.010 and 0.021 requires the following conditions for producing liquid $\mathrm{CaO}-\mathrm{Al}_{2} \mathrm{O}_{3}$ inclusions without formation of $\mathrm{CaS}$.

- The value of $h_{\mathrm{O}}$ should be controlled in the range between 0.001 and 0.0016 shown as shaded area 1 in Fig. 5.

- $h_{\mathrm{Ca}}$ must be carefully controlled in the small range between $4.4 \times 10^{-8}$ and $1.7 \times 10^{-7}$ shown as shaded area 2 in Fig. 5.

- $h_{\mathrm{S}}$ must be below 0.0069 to avoid formation of CaS.

Figure 6 shows the "liquid window" as a plot of $\log h_{\mathrm{S}}$ against $\log h_{\mathrm{A} 1}$ based on the assumption of reaction (5) reaching equilibrium state. Thus, the relation between nozzle clogging and the contents of $\mathrm{Al}$ and $\mathrm{S}$ in the Ca-treated Al-killed steels can be predicted as shown in Fig. 7. In theory, complete or partially solid CA inclusions 


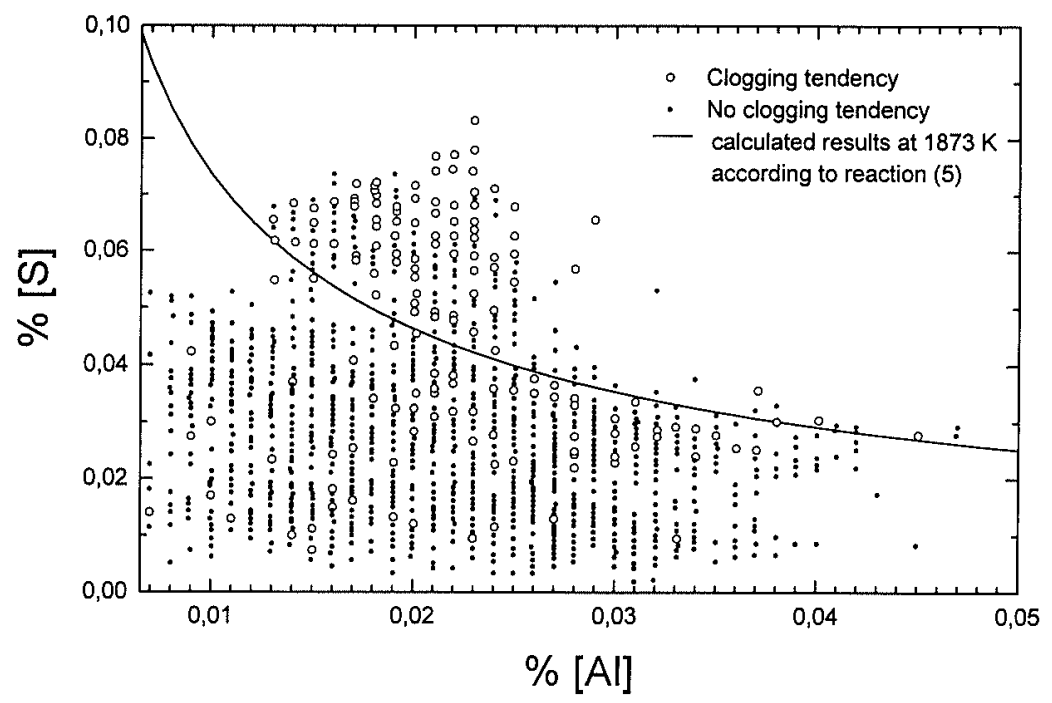

Fig. 7. Theoretical (this paper) and experimental ${ }^{37)}$ results concerning the influence of the contents of $\mathrm{Al}$ and $\mathrm{S}$ on clogging tendency of continuous casting of blooms.

are produced when the points of $\mathrm{Al} v s . \mathrm{S}$ contents lie above the solid line in Fig. 7. The industrial results ${ }^{37)}$ are also plotted in this figure. It can be concluded that the industrial results seem to agree with the theoretical prediction, although the industrial results scattered. It is worth mentioning that the line in Fig. 7 should be a little lower with regard to the contents of $\mathrm{Al}$ and $\mathrm{S}$ because this line represents the activities of $\mathrm{Al}$ and $\mathrm{S}$.

The overall interaction between oxides, sulfides and the bulk can be represented by

$$
(\mathrm{CaO})_{\mathrm{C}-\mathrm{A} \text { incl. }}+[\mathrm{S}]=(\mathrm{CaS})_{\mathrm{CaS}-\mathrm{MnS} \text { incl. }}+[\mathrm{O}]
$$

This reaction indicates the competing relationships of the modification of oxides and sulfides. Figure 8 shows the plot of $\log a_{\text {Cas }}$ versus $\log \left(h_{\mathrm{S}} / h_{\mathrm{O}}\right)$ demonstrating that the initial conditions in the melt determine the modification process. Higher initial ratios $h_{\mathrm{S}} / h_{\mathrm{O}}$ in the melt favour the formation of sulfide inclusions whereas lower initial ratios $h_{\mathrm{S}} / h_{\mathrm{O}}$ favour oxide formation.

\subsection{Thermodynamic Consideration on Practical Ca Treatment}

In practical steelmaking, most steel grades are alloyed with different metals such as $\mathrm{Si}, \mathrm{Mn}$ and $\mathrm{Cr}$ and deoxidized by different elements such as $\mathrm{Si}, \mathrm{Mn}, \mathrm{Al}$ and $\mathrm{Ca}$. Thus, the oxide inclusions tend to form complex oxide inclusions such as $\mathrm{Al}_{2} \mathrm{O}_{3}-\mathrm{SiO}_{2}-\mathrm{CaO}-\mathrm{MnO}$. Normally, $\mathrm{Ca}$ is added to liquid steel as both a purifier and modifier. Ca treatment of liquid steel is experimentally confirmed as a promising way beneficial to the improvement of castibility and properties of steel via the purification of steel and modification of inclusions. ${ }^{10,38)}$ However, the treatment by $\mathrm{Ca}$ is not as convenient as that by $\mathrm{Al}$ because of its low boiling point, high volatility and chemical activity. These prominent characteristics bring about great difficulties in practical operations and determining the thermodynamic behavior of $\mathrm{Ca}$ in liquid steel. Although the thermodynamic behavior of $\mathrm{Ca}$ is still open to discussion on many aspects, some valuable conclusions have been obtained from the pertinent investigations. ${ }^{35,38-43)}$ The main conclusions can be

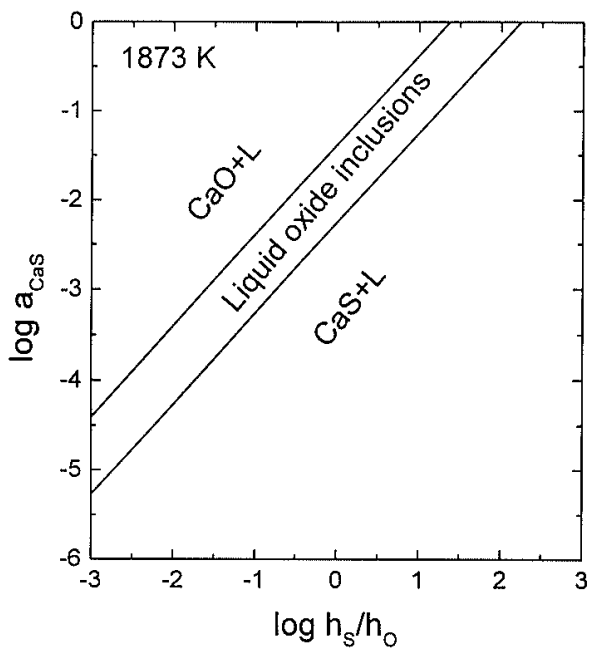

Fig. 8. Competition of oxide and sulfide modification depending on the initial composition of steel.

summarized as follows

- Calcium is soluble in liquid iron at a limited extent. The solubility of $\mathrm{Ca}$ in liquid iron at $1873 \mathrm{~K}$ is in the range of 0.030 to 0.040 mass $\%$.

- The elements $\mathrm{C}, \mathrm{Si}, \mathrm{Mn}, \mathrm{Ni}$ and $\mathrm{Al}$ contribute to an increase of $\mathrm{Ca}$ solubility in liquid iron.

- Extremely strong reactions between $\mathrm{Ca}$ and $\mathrm{O}$ in liquid iron and the characteristics of $\mathrm{Ca}$ mentioned are responsible for the difficulties in determining the interaction parameters between $\mathrm{Ca}$ and $\mathrm{O}$ in liquid iron.

- Dissolved Ca in liquid steel reacts with impurities in the steel and also with oxide and sulfide inclusions to reach the modification of their compositions and morphologies.

The inadequate knowledge on the thermodynamic behavior of $\mathrm{Ca}$ in liquid steel makes the theoretical predictions to solve and/or explain practical problems uncertain. That is why a "general recipe" for the correct amount of $\mathrm{Ca}$ addition has not been achieved so far, although $\mathrm{Ca}$ has been widely used to treat Al-killed steels since the 1970's. In general, practical deoxidation is a 


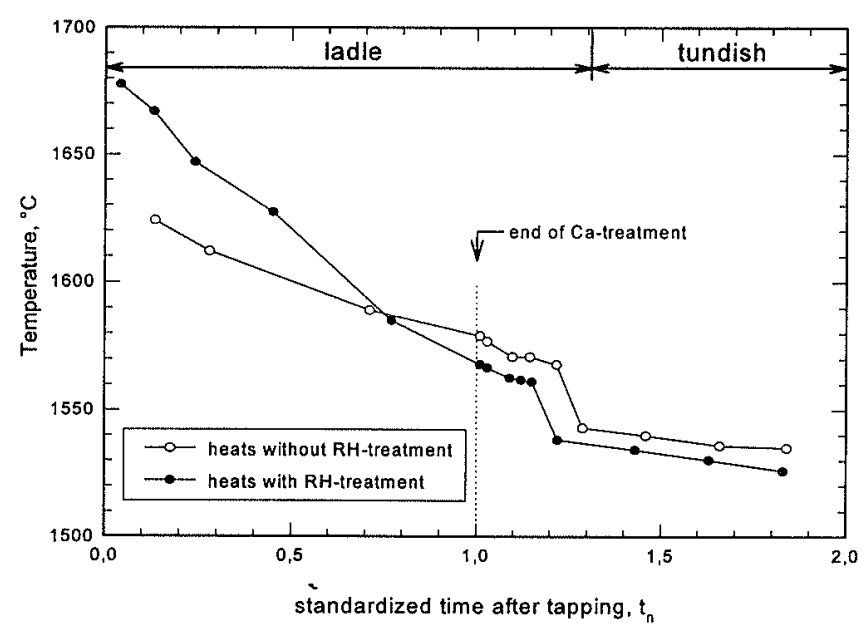

Fig. 9. Temperature of the heats with the without RH treatment.

complex reaction in which many elements such as $\mathrm{Si}$, $\mathrm{Mn}, \mathrm{Al}, \mathrm{Ca}$ and $\mathrm{O}$ are involved. The optimum addition of each deoxidizing element must be found and excesses as well as deficits have to be avoided to prevent unexpected reactions or products. Thus, a deep and systematic investigation on deoxidation is needed both from theoretical and practical views.

\section{Industrial Investigations}

Saarstahl AG is operating a LD-steel plant with one RH-degassing unit and four continuous casting facilities. The production of more than 2 million ton per year includes a large percentage of special steels for bars and rods for the automotive industry facing strict cleanness requirements.

Experiments were carried out to investigate the influence of top slag, oxygen content and inclusions upon the castability of Ca-treated Al-killed steels with high $\mathrm{S}$ contents. Some heats were melted without degassing treatment, the other group was degassed by RH-treatment.

\subsection{Top Slag}

In this investigation experiments were performed with $\mathrm{CaO}$-based slag formers being added into the ladle during tapping. The course of the temperature of the melt is described in Fig. 9 indicating that the RH-treated heats need a higher temperature level in the first half of the intensive ladle treatment for compensation of the temperature losses during the $\mathrm{RH}$ degassing.

In the final part of the ladle treatment and during casting the temperatures are similar for both groups. After tapping, the intensive ladle treatment is characterized by the different steps of the $\mathrm{Si}$ and $\mathrm{Al}$ deoxidation and of the alloying elements to reach the final composition of each heat depending on the requirements of the customer.

After tapping a top slag is coming into existence due to the slag former, the deoxidation products and the wear of the dolomitic ladle refractory. The composition of the top slag is fairly constant during ladle treatment (Fig. 10). The main components are $\mathrm{CaO}, \mathrm{Al}_{2} \mathrm{O}_{3}$ and $\mathrm{SiO}_{2}$.

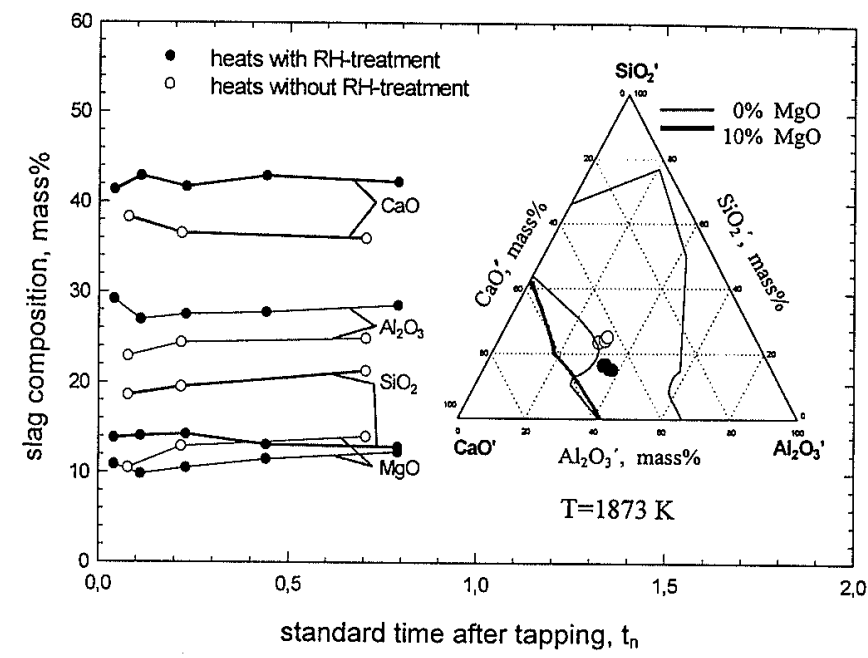

Fig. 10. Composition of the top slag and its position in the ternary system $\mathrm{CaO}-\mathrm{Al}_{2} \mathrm{O}_{3}-\mathrm{SiO}_{2}$.

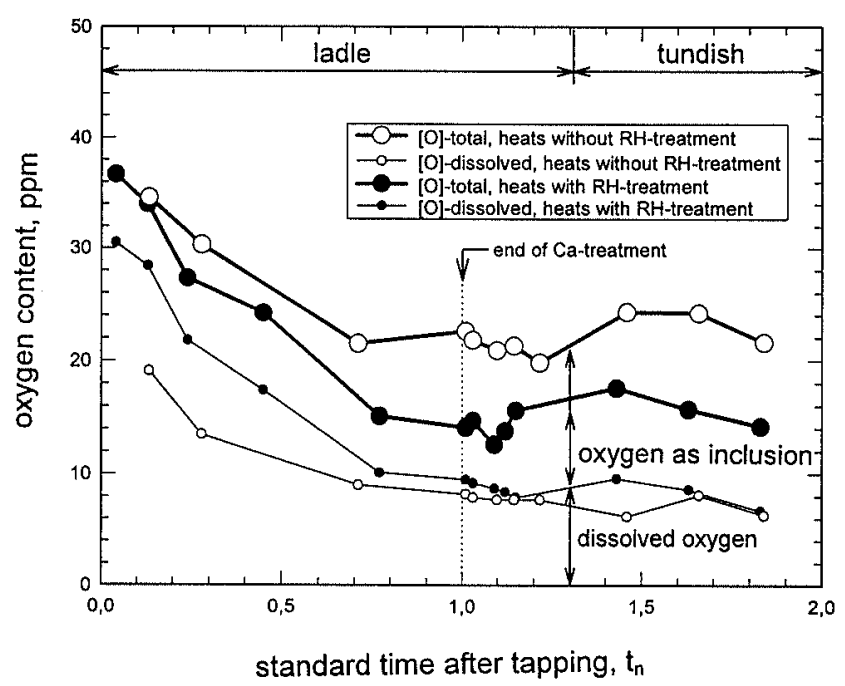

Fig. 11. Course of the total and the dissolved oxygen.

The $\mathrm{MgO}$ content is of the order of $10 \%$. The top slag is liquid evaluated from $\mathrm{CaO}-\mathrm{SiO}_{2}-\mathrm{Al}_{2} \mathrm{O}_{3}-10 \% \mathrm{MgO}$ phase diagram. The heats with $\mathrm{RH}$ degassing exhibits a higher $\mathrm{CaO}$ and $\mathrm{Al}_{2} \mathrm{O}_{3}$ and a lower $\mathrm{SiO}_{2}$ content. The high contents of $\mathrm{CaO}$ and $\mathrm{Al}_{2} \mathrm{O}_{3}$ contents in the top slag demonstrate a lower oxygen level in steel melts resulting in a low content of $\mathrm{SiO}_{2}$ in the top slag.

\subsection{Oxygen Content}

For a better understanding of the deoxidation process, the oxygen content was determined during ladle treatment and during casting in the tundish. After tapping the total content of oxygen, $O_{\text {tot }}$, is in the range of $35-40 \mathrm{ppm}$ due to $\mathrm{Al}$ deoxidation. During the following ladle treatment $O_{\text {tot }}$ of the heats without RH treatment is lowered to $20-25 \mathrm{ppm}$ in the tundish (Fig. 11). The $O_{\text {tot }}$ level of the RH degassed heats is even lower reaching $10-20 \mathrm{ppm}$ in the tundish. In addition, oxygen activities were measured by oxygen sensors ranging from 5 to $25 \mathrm{ppm}$ after tapping and 2 to $5 \mathrm{ppm}$ in the tundish. Those values are close to the equilibrium values.

Using thermodynamic data for liquid dilute iron alloys, ${ }^{20,44,45)}$ the first-order interaction coefficients and 

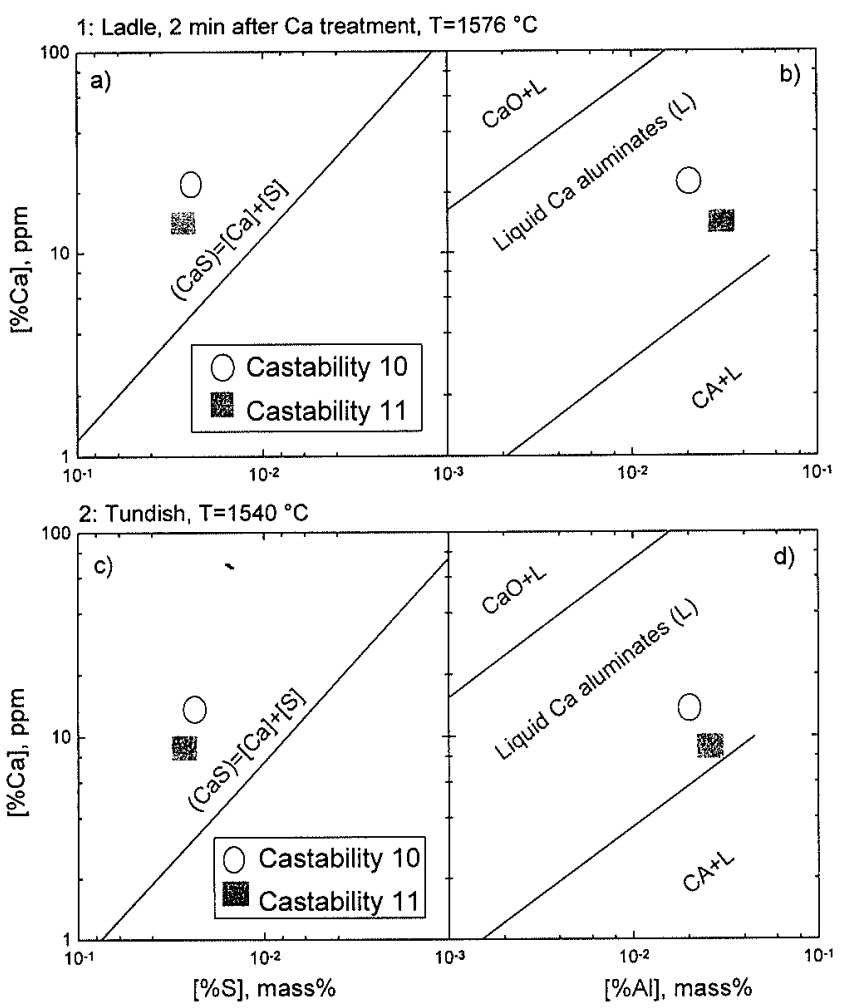

Fig. 12. Position of the heats without RH treatment in the system $\mathrm{Fe}-\mathrm{Al}-\mathrm{O}-\mathrm{Ca}-\mathrm{S}$.

the composition of the melt, the dissolved oxygen $\left(O_{\text {dis }}\right)$ can be calculated. The result of these calculations is shown in Fig. 11, too.

The dissolved oxygen content is of course always lower than $O_{\text {tot }}$. It can be seen that the level of the dissolved oxygen of the degassed heats is higher in the first half of the ladle treatment compared with the heats without $\mathrm{RH}$ degassing. The reason for this is the higher level of temperature. After $\mathrm{Ca}$ treatment the dissolved oxygen content of the two groups is of the same order.

The oxygen as inclusions present in steel melts, $O_{\text {incl. }}$, equals the difference between the total oxygen and dissolved oxygen content, i.e. $O_{\text {tot }}-O_{\text {dis }}$ In such a way it is possible to obtain both the $O_{\text {dis }}$ and $O_{\text {incl. }}$ during melting and casting. It is obvious from Fig. 11 that the RH-treated heats give a considerably lower $O_{\text {incl. }}$ in comparison with the non-degassed heats.

\subsection{Castability and Liquid Window}

Castability is a frequently used concept which is closely related to fluidity, chilling tendency and shrinkage characteristics. Unfortunately, there exists no certain definition for castability. Castability is a relative concept depending on factors such as the kind of metal and different processes. For continuous casting processes, castability may enhance fluidity of steel melts and nozzle clogging tendency. In the present paper, the castability index is determined by the course or the movement of the stopper rod during casting. Castability index 10 is standing for an excellent fluidity without clogging, 11 for good fluidity without clogging, 12 for bad fluidity with clogging indicating the formation of deposits and 13 for very bad fluidity together with serious clogging. It is
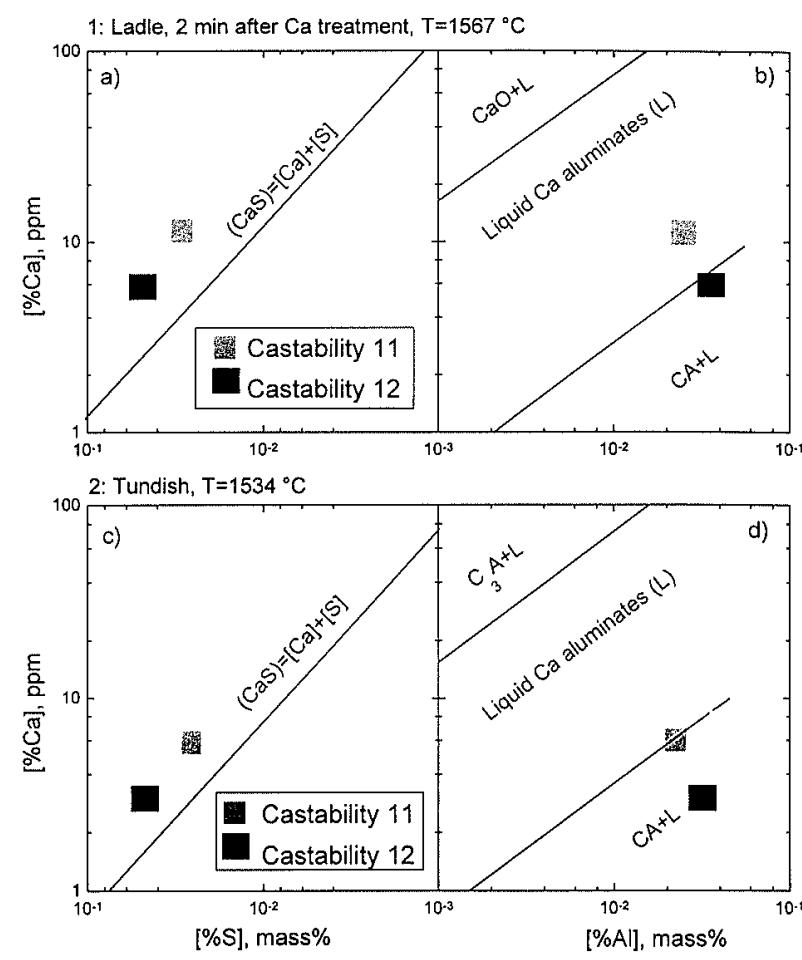

Fig. 13. Position of the RH-treated heats in the system $\mathrm{Fe}-\mathrm{Al}-\mathrm{O}-\mathrm{Ca}-\mathrm{S}$

believed that steel castability will be greatly improved if the inclusions in steel melts are in liquid rather than solid state. The term "liquid window" is used to express the conditions to generate liquid inclusions. Figures 12 and 13 show the conditions generating liquid $\mathrm{Ca}$ aluminates resulting from the calculations of equilibria in the $\mathrm{Fe}-$ $\mathrm{Al}-\mathrm{O}-\mathrm{Ca}-\mathrm{S}$ system at high temperatures. ${ }^{46)}$

The heats with $\mathrm{Ca}$ treatment were reached by feeding CaSi-filled wire into the melts. Samples were taken from steel melts in the ladle and in the tundish during casting. The composition positions of the heats with good castability and with or without $\mathrm{RH}$ treatment (castability 10 and 11 ) are located in the liquid window (Fig. 12(b, d), Fig. 13(b, d)). The composition positions of the heats with poor castability (castability 12) are not situated in the liquid window but in the area of generating high melting $\mathrm{Ca}$ aluminates. $\mathrm{Ca}$ content in steel melts continuously decreases in the tundish because of $\mathrm{Ca}$ evaporation resulting in formation of high melting $\mathrm{Ca}$ aluminates. These results coincide with the above-mentioned result which indicates that steel castability will be greatly improved if the inclusions are in liquid rather than solid state. It is obvious from Fig. 12(a, c) and Fig. 13(a, c) that $\mathrm{CaS}$ is coming into existence because of the high content of $S$ deteriorating the castability. Therefore, exceedingly high $\mathrm{Ca}$ contents are not expected in high S-containing steel melts for avoiding $\mathrm{CaS}$ generation.

It is evident from Figs. 12 and 13 that the liquid window is getting smaller as temperature decreasing. As abovementioned, $\mathrm{Ca}$ content is found to decrease in the tundish resulting from $\mathrm{Ca}$ evaporation. Therefore, stricter requirements should be imposed to control the contents of $\mathrm{Al}, \mathrm{Ca}, \mathrm{S}$ and $\mathrm{O}$ in the tundish for generating liquid 


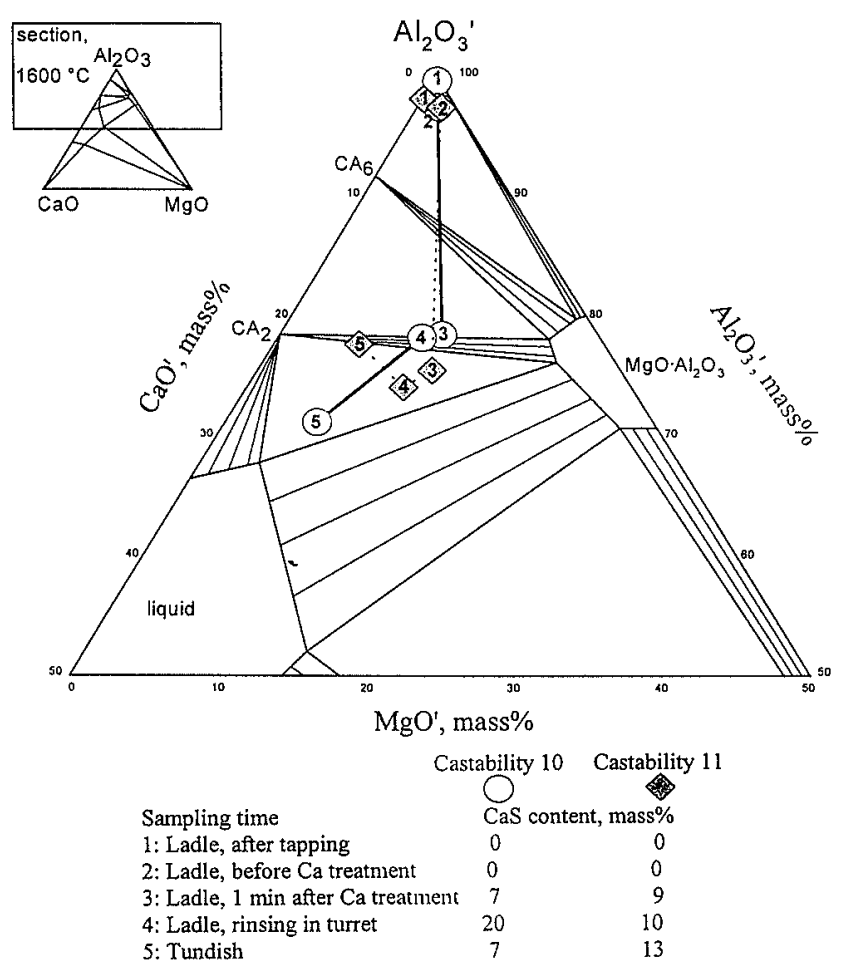

Fig. 14. Position of the inclusions of the heats without RH treatment in the pseudo-ternary system $\mathrm{CaO}^{\prime}-$ $\mathrm{MgO}^{\prime}-\mathrm{Al}_{2} \mathrm{O}_{3}^{\prime}$.

Ca aluminates.

\section{4. $\mathrm{CaO}-\mathrm{MgO}-\mathrm{Al}_{2} \mathrm{O}_{3}$ Inclusions}

For the evaluation of the composition of inclusions generated in refining and casting processes, nearly 1000 analyses have been made. The "inclusion path" of the non $\mathrm{RH}$-treated heats can be described in the pseudoternary system $\mathrm{CaO}^{\prime}-\mathrm{MgO}^{\prime}-\mathrm{Al}_{2} \mathrm{O}_{3}{ }^{\prime}$. After tapping and alloying only $\mathrm{Al}_{2} \mathrm{O}_{3}$ inclusions are formed located in the $\mathrm{Al}_{2} \mathrm{O}_{3}$ corner of the system (positions 1-2, Fig. 14). Two minutes after Ca treatment the inclusions compositions are influenced by the introduction of $\mathrm{CaO}$, but at the same time $\mathrm{MgO}$ is being found. The compositions of inclusions are moving to position 3 consisting of high melting $\mathrm{CA}_{2}$ and $\mathrm{MgO} \cdot \mathrm{Al}_{2} \mathrm{O}_{3}$ spinel with a small portion of liquid $(\mathrm{Ca}, \mathrm{Al}, \mathrm{Mg}) \mathrm{O}$ inclusion. The $\mathrm{CaS}$ content is about $8 \%$.

After rinsing in the turret with a very fine Ar-bubbling for the separation of the inclusions, the composition does not change significantly (point 4 ) with regard to the position in the pseudo-ternary system, but the CaS content is raised to $10-20 \%$, respectively. From this point of view it can be concluded that

- the transformation of the $\mathrm{Al}_{2} \mathrm{O}_{3}$ inclusions into liquid $\mathrm{Ca}$ aluminates needs time

- the formation of $\mathrm{Ca}$ sulfides is retarded but still very effective

- there is a reaction of steel melts and the inclusions with the $\mathrm{MgO}$ of the refractory in the ladle.

In the tundish-during casting - the composition of the inclusions of heats with a good castability is moved to position 5 , indicating that the reaction with the metallic $\mathrm{Ca}$ continues forming more and more liquid $\mathrm{CaO}$-rich

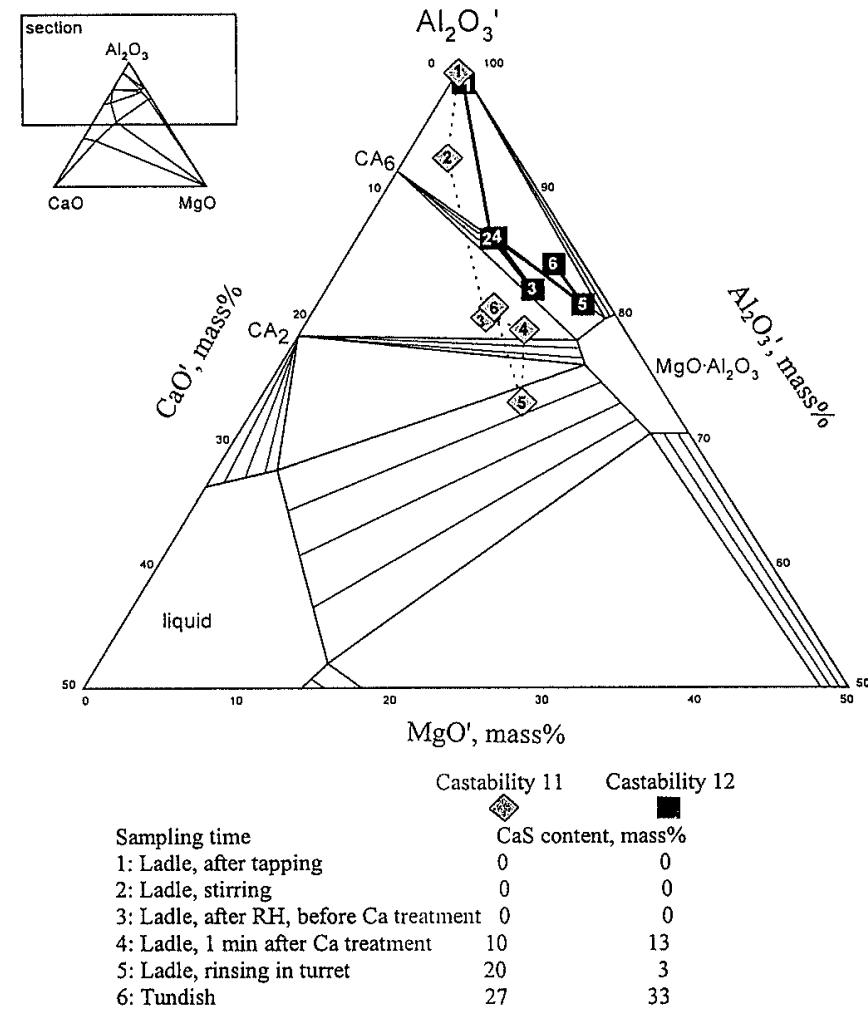

Fig. 15. Position of the inclusions of the RH-treated heats in the pseudo-ternary system $\mathrm{CaO}^{\prime}-\mathrm{MgO}^{\prime}-\mathrm{Al}_{2} \mathrm{O}_{3}{ }^{\prime}$.

inclusions. The $\mathrm{CaS}$ content is lowered to $7 \%$ finally leading to a good castability.

The composition of the inclusions of heats exhibiting a poor castability (point 5, Fig. 14) is similar to the inclusion type of the rinsing section. They consist of high melting $\mathrm{CA}_{2}, \mathrm{MgO} \cdot \mathrm{Al}_{2} \mathrm{O}_{3}$ spinel and $13 \% \mathrm{CaS}$.

The composition of the inclusions of the RH-treated heats with a castability index of 11 is discussed in Fig. 15. Once again, the "inclusion path" starts after tapping at the $\mathrm{Al}_{2} \mathrm{O}_{3}$ corner of the pseudo-ternary system (point 1). But-in contrary to the non-degassed heats-the composition of the inclusions moves towards the edge system $\mathrm{Al}_{2} \mathrm{O}_{3}-\mathrm{MgO}$ already during alloying and rinsing (point 2). After RH degassing (point 3) and Ca treatment (point 4) the position of the inclusions is moved further in the direction of the $\mathrm{MgO} \cdot \mathrm{Al}_{2} \mathrm{O}_{3}$ spinel. There occurs a small $\mathrm{CaS}$ formation after the $\mathrm{Ca}$ treatment $(13 \%$ $\mathrm{CaS}$ ). This movement continues during rinsing in the turret reaching the equilibrium between the liquid phase and the $\mathrm{MgO} \cdot \mathrm{Al}_{2} \mathrm{O}_{3}$ spinel (point 5). Finally, in the tundish, the "inclusion path" turns around due to the increase of the $\mathrm{Al}_{2} \mathrm{O}_{3}$ and particularly of the $\mathrm{CaS}$ content up to $27 \%$ (position 6). It is concluded that this phenomenon is due to the reaction between $\mathrm{CaO}$ in the inclusions and $\mathrm{S}$ and $\mathrm{Al}$ in steel melts according to the overall reaction (5) in the presence of a low oxygen content. It is consistent with the results mentioned in section 2.2 , i.e. higher ratios of $h_{\mathrm{S}} / h_{\mathrm{O}}$ in the melts favour the formation of sulfides, otherwise higher oxygen level favors oxide formation.

The RH-treated heats with a poor castability - castability index 12-feature the same behavior in Fig. 15 but the inclusions are closer to the binary system $\mathrm{MgO}$ 


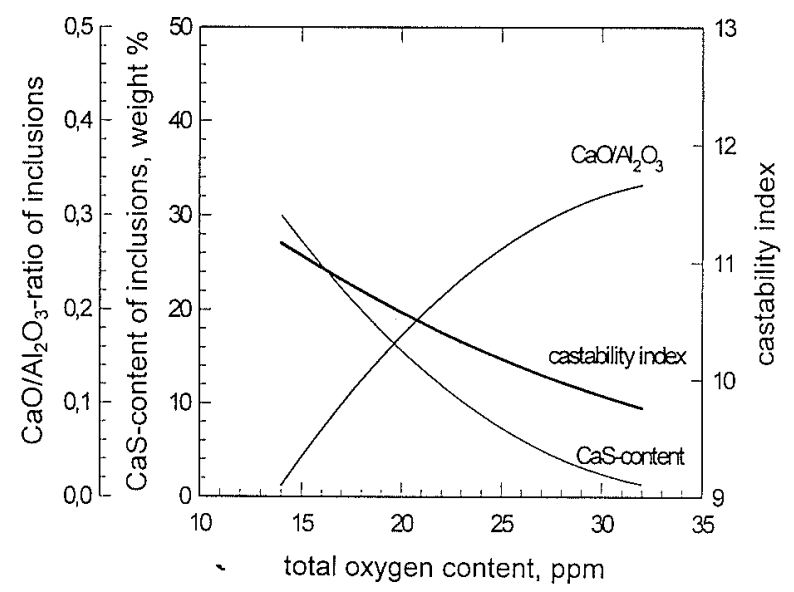

Fig. 16. Influence of oxygen in the steel and CaS content and $\mathrm{CaO} / \mathrm{Al}_{2} \mathrm{O}_{3}$ ratio in the inclusions on the castability.

$\mathrm{Al}_{2} \mathrm{O}_{3}$. In the tundish, the inclusions are showing even higher $\mathrm{Al}_{2} \mathrm{O}_{3}$ and $\mathrm{CaS}$ contents.

\subsection{Castability}

According to the results of the present investigation, castability is influenced by many factors such as $\mathrm{CaO} / \mathrm{Al}_{2} \mathrm{O}_{3}, \mathrm{CaS}$ content and $\mathrm{O}_{\text {tot. }}$ shown in Fig. 16 .

The castability of Ca-treated Al-killed heats will be improved by

- a higher oxygen level in the liquid steel

- a high $\mathrm{CaO} / \mathrm{Al}_{2} \mathrm{O}_{3}$ ratio in the inclusions indicating an effective $\mathrm{Ca}$ treatment and inclusions located within the liquid window.

A deterioration of the castability is taking place by both

- the reaction between the $\mathrm{CaO}$ in the inclusions and the $\mathrm{S}$ and $\mathrm{Al}$ in the liquid steel in the presence of a low oxygen content favouring the formation of additional $\mathrm{Al}_{2} \mathrm{O}_{3}$, and

- the formation of inclusions with high melting point such as $\mathrm{CA}_{2}$ and $\mathrm{MgO} \cdot \mathrm{Al}_{2} \mathrm{O}_{3}$.

\section{Results and Discussions}

A tight control of both the top slag and the oxygen content of $\mathrm{Al}$ deoxidized heats with $\mathrm{S}$ contents in the range of $0.020-0.050 \%$ is needed to produce clean steel in order to meet the strict quality requirements of the automotive industry. From this point of view, ladle metallurgy is favouring oxygen contents as low as possible to achieve high oxide cleanness. Therefore, $\mathrm{Ca}$ treatment was introduced into ladle metallurgy with regard to the formation of liquid $\mathrm{Ca}$ aluminates to establish and to maintain a good castability particularly for sequence casting.

The results of the present investigations make clear that there exists an "inclusion path" during the ladle treatment influencing the formation of the inclusion prior to the Ca treatment. At the moment of the formation of high melting $\mathrm{MgO} \cdot \mathrm{Al}_{2} \mathrm{O}_{3}$ spinel, the traditional $\mathrm{Ca}$ treatment is affected leading to inclusions with a low $\mathrm{CaO} / \mathrm{Al}_{2} \mathrm{O}_{3}$ ratio and high $\mathrm{S}$ contents and resulting in a poor castability. Therefore, $\mathrm{Ca}$ treatment must be corrected taking these reactions into consideration.

\section{Conclusions}

Thermodynamic fundamentals on the systems $\mathrm{Fe}-$ $\mathrm{Al}-\mathrm{O}$ and $\mathrm{Fe}-\mathrm{Al}-\mathrm{Ca}-\mathrm{S}-\mathrm{O}$ are analysed and discussed. A "liquid window" indicating the formation of liquid $\mathrm{Ca}$ aluminates in liquid steel is pursued to improve castability of Ca-treated Al-killed steels. Both industrial investigations with and without $\mathrm{RH}$ treatment confirmed this conclusion.

The top slag of degassed heats provides a lower oxygen potential than that of non-degassed heats, although its composition is fairly constant during ladle treatment for both degassed and non-degassed heats, respectively. The measured oxygen activities show that the oxidation reaction after tapping and in the tundish approximately reaches equilibrium. The dissolved oxygen of degassed heats is higher than that of non-degassed heats. It is experimentally demonstrated that the oxygen as inclusion for degassed heats is considerably lower compared to the non-degassed heats.

The present investigation clearly shows that there exists an "inclusion path" during the ladle treatment largely influencing the formation of liquid $\mathrm{Ca}$ aluminates. The inclusion path for the heats with RH treatment markedly differs from the heats without $\mathrm{RH}$ treatment. This may be mainly caused by the oxygen level. A very low oxygen level easily leads to the formation of $\mathrm{MgO} \cdot \mathrm{Al}_{2} \mathrm{O}_{3}$ spinel via the reaction between liquid steel and ladle refractory, the decrease of the $\mathrm{CaO} / \mathrm{Al}_{2} \mathrm{O}_{3}$ ratio caused by reaction (5), and the formation of $\mathrm{CaS}$ via reaction (5). This results in a poor castability. Therefore, $\mathrm{Ca}$ treatment must be corrected taking the above mentioned phenomena into account. Normally, the following conditions favour the prevention of the formation of harmful inclusions and improvement of castability of Ca-treated Al-killed steels: - a suitable oxygen level in the liquid steel avoiding the formation of $\mathrm{MgO} \cdot \mathrm{Al}_{2} \mathrm{O}_{3}$ spinel

- inclusions with a high $\mathrm{CaO} / \mathrm{Al}_{2} \mathrm{O}_{3}$ ratio indicating an effective $\mathrm{Ca}$ treatment and inclusions located in the range of the liquid window.

\section{Acknowledgements}

The authors wish to express their thanks to the European Coal and Steel Community (ECSC) for financial support under grant No. 95-C2.03c and 95-C2.03a.

\section{REFERENCES}

1) Z. Ma. A. Franke and D. Janke: "Improvement of castibility and quality of continuously cast steel by alternative deoxidation techniques", Technical report. TU Freiberg. (1999).

2) S. Dimitrov, A. Weyl and D. Janke: Steel Res., 66 (1995), 3.

3) T. B. Braum, J, F. Elljott and F. C. Flemings: Metall. Trans. B, 10B (1979), 171

4) W. K. Tiekink, A. Pieters and J. Hekkema: Iron Steelmaker, 21 (1994), 39.

5) M. Akiyoshi, M. Wako, H. Misumi and A. Kasama: CAMP-ISIJ, 7 (1994), 1131.

6) H. Tozawa, Y. Kato and K. Nakanishi: CAMP-ISIJ, 7 (1994). 276.

7) Z. Ma and D. Janke: Technical report "Improvement of nonmetallic inclusions and fine grain structures of continuously cast steel by oxide metallurgy" the European Coal and Steel 
Community (ESCS) sponsored project under grant No. 95-C2.03c, Institute of Iron and Steel Technology of Freiberg University of Mining and Technology, (1997).

8) H. Yin, H. Shibata, T. Emi and M. Suzuki: ISIJ Int., 37 (1997), 936

9) T. Uesing: Trans. Iron Steel Inst. Jpn., 26 (1986), 614.

10) T. Ototani: Calcium clean steel, Springer-Verlag, Berlin, (1986).

11) H. K. Tönshoff, W. Kaestner and R. Schnadt: Stahl Eisen, 109 (1989), 743.

12) Z. Ma, D. Peisker and D. Janke: Steel Res., 70 (1999), 178.

13) Z. Ma and D. Janke: 3rd CAST (China Association of Science and Technology) Conf. of Young Scientists, Vol. Materials Science and Industrial Technology, China Press of Science and Technology, Beijing, (1998), 46.

14) T. Takamura and S. Mizoguchi: 6th Int. Iron Steel Cong., Vol. 3, ISIJ, Tokyo, (1990), 591 and 598.

15) T. Sawai, M. Wakoh, Y. Ueshima and S. Mizoguchi: 6th Int. Iron Steel Cong., Vol. 3, ISIJ, Tokyo, (1990), 605.

16) S. Ogibayashi, K. Yamaguchi, M. Hirai and H. Goto: 6th Int. Iron Steel Cong., Vol. 3, ISIJ, Tokyo, (1990), 612.

17) Z. Ma and D. Janke: ISIJ Int., 38 (1998), 46.

18) Z. Ma and D. Janke: Acta Met. Sin. (Engl. Ed.), 11 (1998), 79.

19) Z. Ma and D. Janke: Technical report "Improvement of fine grain structures 27MnSiVS steel", Institute of Iron and Steel Technology of Freiberg University of Mining and Technology, (1998).

20) Steelmaking data sourcebook: Revised edition by the Japan Society for the Promotion of Science, Gorden and Beach Science Publishers, New York, (1988).

21) L. E. Rhode, A. Choudhury and M. Wahister: Arch. Eisenhüttenwes., 42 (1971), 165.

22) J. D. Jeo, S. H. Kim and K. R. Lee: Steel Res., 69 (1998), 49.

23) J. C. D'Entremont, D. J. Guernsey and J. Chipman: Trans. Met. Soc. AIME, 227 (1963), 14.

24) A. McLean and H. B. Bell: J. Iron Steel Inst, 203 (1965), 123.

25) R. J. Fruehan: Metall. Trans., 1 (1970), 3403.

26) D. Janke and W. A. Fischer: Arch. Eisenhüttenwes., 47 (1976),
195.

27) D. Janke: Proc. 2nd Int. Conf. on Clean Steel, The Metal Soc., London, (1983), 202.

28) J. F. Elliott, M. Gleiser and V. Ramakrishna: Thermochemistry for steelmaking, Addison-Wesley, Reading, MA, Vol. 2, (1963), 491.

29) H. Suito, H. Inoue and R. Inoue: ISIJ Int, 31 (1991), 1381.

30) Slag Altas: 2nd Ed., ed. by Verein Duetscher Eisenhüttenluete (VDEh), Verlag Stahleisen GmbH, Düsseldorf, (1995), 39.

31) V. Presern, B. Korousic and J. W. Hastie: Steel Res, 62 (1991), 289.

32) E. T. Turkdogan: Steel Res., 62 (1991), 379.

33) P. J. Spencer: Steel Res., 62 (1991), 382.

34) D. Janke: Steel Res., 62 (1991), 383.

35) H. Fujiwara, M. Tano, K. Yamamoto and E. Ichise: ISIJ Int, 35 (1995), 1063.

36) S. W. Cho and H. Suito: ISIJ Int., 34 (1994), 265.

37) L. E. Holappa and R. V. Väinölä: XL VIII Berg-und Hüttenmännischer Tag, Freiberg, TU Freiberg, (1996), paper 3.

38) E. T. Turkdogan: Reprints of papers of the International Calcium Treatment Symposium, University of Strathclyde, Glasgow, (1986), $2-1$.

39) F. Wever: Arch. Eisenhüttenwes., 2 (1929), 739

40) D. L. Sponseller and R. A. Flim: Trans. Metall. Soc. AIME, 230 (1964), 876.

41) M. Köhler and D. Janke: Steel Res., 56 (1985), 419.

42) S. W. Cho and H. Suito: ISIJ Int., 34 (1994), 265.

43) B. Song, and Q. Han: Metall. Mater. Trans. B, 29B (1998), 415.

44) H. Schenk and E. Steinmetz: Stahleisen-Sonderberichte, 8 (1968), No. 7, Verlag Stahleisen mbH, Düsseldorf.

45) J. Härkki, K. Jylhä, Y. Julin, A. Taskinen: Technical report, Helsinki University of Technology, Institution of Process Metallurgy, (1983).

46) H. Gaye, D. C. Gatellier, M. Nadif, P. V. Riboud, J. Saleil and J. Faral: Proc: Cong. "Clean steel 3", The Metals Soc., London, (1986), No. 5, 433. 